\title{
O CAPITALISMO CHEGA A SEU FIM
}

Entrevista concedida por Immanuel Wallerstein, pesquisador do Depto de Sociologia da Universidade de Yale, EUA, ex-presidene da Associação Internacional de Sociologia.

\author{
Le Monde , Paris, 12.10.08.http://www.lemonde.fr/la-crise- \\ financiere/article/2008/10/11/le-capitalisme-touche-a-sa-fin 1105714 1101386.html
}

(Acesso em 12/10/2008).

Tradução: Valdemar Sguissardi (Piracicaba, 18 de outubro de 2008)

Le Monde: Signatário do Manifesto do Fórum Social de Porto Alegre ("Doze proposições para um outro mundo possível"), em 2005, o Sr. é considerado um dos inspiradores do movimento altermundialista. O Sr. fundou e dirigiu o Centro Fernand-Braudel para o estudo da economia dos sistemas históricos e das civilizações, da Universidade do Estado de Nova Yorque, em Birghamton. Como o Sr. situa a crise econômica e financeira atual no "tempo longo" da história do capitalismo?

Immanuel Wallerstein: Fernand Braudel (1902-1985) distinguia o tempo da "longa duração", que vê se sucederem na história humana sistemas regendo as relações do homem com seu meio ambiente material e, no interior dessas fases, o tempo de ciclos longos conjunturais, descritos por economistas como Nicolas Kondratieff (1882-1930) ou Joseph Schumpeter (1883-1950). Estamos hoje claramente numa fase B de um ciclo de Kondratieff, que começou há trinta ou trinta e cinco anos, após um fase A, que foi a mais longa (de $1945 \mathrm{a}$ 1975), dos quinhentos anos da história do sistema capitalista.

Numa fase $A$, o lucro é gerado pela produção material, industrial ou outra; numa fase $B$, o capitalismo deve, para continuar a produzir lucro, financeirizar-se e refugiar-se na especulação. Há mais de trinta anos, as empresas, os Estados e as famílias endividam-se massivamente. Estamos hoje na última parte de uma fase $\mathrm{B}$ de Kondratieff, quando o declínio virtual torna-se real, em que as bolhas explodem umas após outras: as falências multiplicam-se, a concentração do capital aumenta, o desemprego avança e a economia conhece uma situação de deflação real.

Mas, hoje, este momento do ciclo conjuntural coincide com - e conseqüentemente o agrava - um período de transição entre dois sistemas de longa duração. Penso que de fato entramos, há trinta anos, na fase terminal do sistema capitalista. O que fundamentalmente diferencia esta fase da sucessão ininterrupta dos ciclos conjunturais anteriores é que o capitalismo não consegue mais "tornar-se sistema", no sentido que the dá o físico e químico llya Prigogine (1917-2003): quando um sistema, biológico, químico ou social, desvia-se demais e muito freqüentemente de sua situação de estabilidade, não consegue mais reencontrar o equilíbrio, e, então, se observa uma bifurcação.

A situação torna-se caótica, incontrolável pelas forças que a dominaram até então, e vêse emergir uma luta, não mais entre os "donos" e os adversários do sistema, mas entre todos 
issn: $1808-799 X$

ano 6 - número 7 - 2008

os atores para determinar o que o vai substituir. Eu reservo o uso do termo "crise" a este tipo de período. Pois bem, estamos em crise. O capitalismo chega a seu fim.

Le Monde: Por que não se trataria antes de uma nova mutação do capitalismo, que já conheceu, além de tudo, a passagem do capitalismo mercantil ao capitalismo industrial; depois, do capitalismo industrial ao capitalismo financeiro?

Immnuel Wallerstein: O capitalismo é onívoro, obtendo o lucro onde ele seja maior num momento dado; não se contenta com pequenos lucros marginais; ao contrário, maximiza-os criando monopólios - ainda recentemente tentou fazê-lo nas biotecnologias e nas tecnologias da informação. Mas eu penso que as possibilidades de acumulação real do sistema atingiram seu limite. O capitalismo, desde seu nascimento na segunda metade do Século XVI, nutre-se do diferencial de riqueza entre um centro, para onde convergem os lucros, e as periferias (não necessariamente geográficas) cada vez mais empobrecidas.

Desse ponto de vista, a recuperação econômica da Ásia do Leste, da Índia, da América Latina constitui um desafio insuperável pela "economia-mundo" criada pelo Ocidente, que não consegue mais controlar os custos da acumulação. As três curvas mundiais dos preços - da mão-de-obra, das matérias-primas e dos impostos - estão, por tudo, em forte alta há decênios. O curto período neoliberal que está se acabando inverteu apenas provisoriamente a tendência: ao final dos anos 1990 esses custos estavam, é verdade, menos elevados quem em 1970, mas estavam muito mais altos que em 1945. Na verdade, o último período de acumulação real - os "trinta anos gloriosos" - somente foi possível porque os Estados keynesianos colocaram suas forças a serviço do capital. Mas, ainda então, o limite foi atingido!

Le Monde: Há precedentes da fase atual, como o Sr. as descreve?

Immanuel Wallertein: Existiram muitos na história da humanidade, contrariamente à imagem, forjada nos meados do Século XIX, de um progresso contínuo e inevitável, inclusive em sua versão marxista. Prefiro me apoiar na tese da possibilidade do progresso, não na de sua inevitabilidade. Certamente, o capitalismo é o sistema que soube produzir, de forma extraordinária e marcante, o máximo de bens e de riquezas. Mas é preciso olhar a soma de perdas - para o meio-ambiente, para as sociedades - que engendrou. $O$ único bem é aquele que permite obter, para o maior número de pessoas, uma vida racional e inteligente.

Dito isso, a crise mais recente, similar à de hoje, foi o desmoronamento do sistema feudal na Europa, entre os meados dos Séculos XV e XVI, e sua substituição pelo sistema capitalista. Esse período, que culminou com as guerras de religião, viu desmoronar as autoridades reais, senhoriais e religiosas sobre as mais ricas comunidades camponesas e sobre as cidades. Foi ali que se construíram, por tateios sucessivos e de forma inconsciente, soluções inesperadas cujo sucesso acabará por "fazer sistema", apresentando-se pouco a pouco sob a forma do capitalismo.

Le Monde: Quanto tempo deverá durar a transição atual e no que poderá desembocar?

Immanuel Wallerstein: $O$ período de destruição do valor que encerra a fase B de um ciclo de Kondratieff dura geralmente de dois a cinco anos antes que sejam reunidas as condições de entrada numa fase $A$, quando um lucro real pode novamente ser conseguido de novas produções materiais descritas por Schumpeter. Mas o fato de que essa fase corresponde atualmente a uma crise do sistema nos fez entrar num período de caos político durante o qual os atores dominantes, à testa das empresas e dos Estados ocidentais, farão tudo o que lhes é tecnicamente possível para reencontrar o equilíbrio, mas é muito provável que não o consigam.

Os mais inteligentes já têm compreendido que teria sido necessário fazer qualquer coisa de inteiramente novo. Mas múltiplos atores já estão agindo, de forma desordenada e 
issn: $1808-799 \mathrm{X}$

ano 6 - número 7 - 2008

inconsciente, para fazer emergirem novas soluções, sem que se saiba inda qual sistema surgirá desses tateios.

Estamos numa período, bastante raro, no qual a crise e a impotência dos poderosos deixam um lugar ao livre arbítrio de cada um: existe hoje um lapso de tempo durante o qual cada um de nós tem a possibilidade de influenciar o futuro por nossa ação individual. Mas como este futuro será a soma do número incalculável destas ações, é absolutamente impossível prever que modelo finalmente se imporá. Dentro de dez anos, pode ser que se veja mais claro; dentro de trinta ou quarenta anos, um novo sistema terá emergido. Creio que é possível tanto ver instalar-se um sistema de exploração, infelizmente, ainda mais violento que 0 capitalismo, quanto ver, ao contrário, instalar-se um modelo mais igualitário e redistributivo.

Le Monde: As mutações anteriores do capitalismo têm muitas vezes desembocado sobre um deslocamento do centro da "economia-mundo", por exemplo da bacia mediterrânea para a costa atlântica da Europa, depois para a dos EUA? O sistema por vir estará centrado na China?

Immanuel Wallerstein: A crise que vivemos corresponde também ao fim de um ciclo político, o da hegemonia americana, desencadeada igualmente nos anos 1970. Os EUA continuarão sendo um ator importante, mas não poderão jamais reconquistar sua posição dominante em face da multiplicação dos centros de poder, com a Europa ocidental, a China, o Brasil, a Índia. Um novo poder hegemônico, se a gente se refere ao tempo longo braudeliano, pode levar ainda cinqüenta anos para se impor. Mas eu ignoro qual.

Enquanto se espera, as conseqüências políticas da crise atual serão enormes, na medida em que os "donos" do sistema irão tentar encontrar bodes expiatórios para o desmoronamento de sua hegemonia. Eu penso que a metade do povo americano não aceitará o que está se passando. Os conflitos internos vão, portanto, exacerbar-se nos EUA, que estão a ponto de se tornarem o país mais instável politicamente do mundo. $E$ não esqueçais que nós, os americanos, estamos todos armados...

Depoimento recolhido por Antoine Reverchon. 